\title{
Nursing Student's Knowledge about Understanding and Prevention of Needle Stick Injury
}

1 Sanja Ledinski Fičko

2 Matija Mlinar

1 Ana Marija Hošnjak

1 Martina Smrekar

1 Biljana Kurtović

${ }^{1}$ Janko Babić

1 University of Applied Health Sciences, Zagreb, Croatia

2 Department of Cardiac Surgery, UHC Zagreb, Croatia

Article received: 26.02 .2020 .

Article accepted: 30.03.2020.

DOI: $10.24141 / 2 / 4 / 1 / 6$

Author for correspondence:

Sanja Ledinski Fičko

University of Applied Health Sciences

Mlinarska cesta 38, Zagreb, Croatia

E-mail: sanja.ledinski-ficko@zvu.hr

Keywords: needle stick injury (NSI), nursing students, prevention programs

\section{Abstract}

Introduction. Needle stick injury (NSI) is an occupational health and safety issue. Nursing students are prone to NSI due to lack of experience with handling needles and sharps.

Aim. To determine the level of knowledge about the prevention of NSI and examine the level of knowledge about the post-exposure procedure and the students' understanding of NSI.

Methods. The study was conducted in 2017 at the University of Applied Health Sciences in Zagreb. The participants were nursing students from all regions of Croatia. The data was collected using a questionnaire containing 17 questions specifically designed for this study. One question had three subquestions and one had five subquestions regarding the knowledge of how to react if a needle stick injury occurs. The participants also responded to a questionnaire on their socio-demographic data.

Results. The study included 149 students. The results show that 16 students have experienced NSI. A statistically significant difference was observed among students who have finished a secondary medical school in the answers about post-NSI interventions and in answers to the question of whether the needle should be recapped. The respondents from medical schools answered correctly. A statistically significant difference was observed among students from non-medical secondary schools in the answers about education on post-exposition procedures and in the answers about necessary action following a needle stick injury. The respondents from non-medical secondary schools had higher scores.

Conclusion. The results of this study can be used to establish appropriate education strategies, increase the awareness of needle stick injuries and minimize the occurrence of these injuries among nursing students in Croatia. 


\section{Introduction}

A needle stick injury (NSI) is any injury caused by a sharp object which does not have to require special care but can lead to infection transmission due to the infected object (needle, ampoule, scalpel). More than 20 pathogens that can transmit infection have been registered, and the most dangerous infections are hepatitis C (HCV), hepatitis B (HBV) and the human immunodeficiency virus (HIV). NSI usually occurs when using therapy or diagnostic procedures, and the most common incidents occur with previously used needles. Administering injections, blood sampling, recapping of needles, discarding needles, handling trash and dirty linen (downstream injuries) and missing the target while transferring blood or any kind of fluid from a syringe to a specimen container (such as a vacuum tube) are the main causes of needle stick injuries (1). The occurrence of NSIs is significantly higher than present estimates suggest, which is why the lower frequency of reporting injuries should not be confused with an absence of a problem (2). That is why it is important to emphasize the promotion of "no guilt" culture: do not let the person who has experienced the incident feel guilty.

Nursing is a practical profession, which is why nursing education comprises both classroom teaching and clinical practice (3). Performing an intervention in a safe and proper way in patient care has a major role in the safety of health professionals, including nursing students. In their clinical placement, nursing students are expected to practice, under supervision, all nursing skills performed by registered nurses, including giving injections via various routes and measuring patient blood glucose using the glucometer. However, nursing students are less experienced and less skilful in handling needles and sharps (4). Prasuna et al. have found a high rate of needle stick injuries among nursing students, as well as a high rate of under-reported cases. These facts and issues need to be highlighted through regular education on real-life procedures at the entry level and a simplified reporting system, thus providing a more user-friendIy platform for reporting NSI. It is very important that students report NSI cases according to a well-established system so they can receive rapid and appropriate post-exposure prophylaxis (2). In the study of Smith and Leggat, $13.9 \%$ of nursing students report- ed a needle stick or sharps injury. Opening the needle cap was the most common causative event $(28 \%$ of all cases), and a total of $39.5 \%$ of NSIs were not reported (5). Talas has reported that $49 \%$ of students in her study reported NSI, where $74 \%$ of these were injured while on wards. She suggests more intensive education programs directed at students in order to increase their awareness of and compliance with universal safety precautions for NSIs (6). Smith and Leggat have stated that such education should incorporate high-risk procedures such as taking the cap off a needle and opening an ampoule (5). Yao et al. have identified insufficient awareness of occupational safety and limited work experience with handling needle stick injuries in nurse students. The authors also state that, when stratified by departments, the highest rate of needle stick injuries was seen in the surgery department (7). Nursing students should be more careful during the disposal of sharps according to Shiao et al. The authors also stated that any public health and infection control strategy should include a universal catch-up HBV vaccination program among students before commencement of internship (8).

Suliman et al. have conducted a cross-sectional study to measure student nurses' level of knowledge about NSIs. The study reported that most of the students who had suffered NSI did not inform their clinical instructors (67.1\%) or write an incident report (86.3\%). The results showed that there was significant difference between students in different years of study. Focusing on NSI in the nursing curriculum and providing more protection and post-exposure intervention for students during their clinical practice is highly recommended (9). There is a need for better education of nursing students and more effective supervision in relation to NSIs and sharps injuries (10). In their literature review, Handiyani et al. identified four main strategies to prevent NSIs, such as education, training, safe needle use and effective communication. Collaboration between hospitals and educational institutions is essential for developing effective NSI prevention programs (11). An educational program (lectures on the risk of unsafe practices and how to avoid them) conducted on the prevention of percutaneous injuries (PIs) showed a significant decrease of PIs rates among nurses. There was a significant decrease in PIs frequency in both the emergency department (3.4\% vs $12.4 \%$ ) and the intensive care unit (3.4\% vs $13.7 \%$ ) (12). The rate of NSIs among nursing students was relatively high before occupational 
safety training and education programs (OSTEP) in China (on average, 4.65 events/nurse). However, it decreased rapidly to 0.16 events/nurse on average after the OSTEP (13). Education on NSIs should include safe working procedures, as well as why NSIs should be reported, using safe tools for needles, safe waste disposal and using containers for sharp objects, as well as incident procedures - including how and when to seek support. After education, what is learnt needs to be applied in practice.

In Croatia, there is a lack of studies about knowledge of NSI among nursing students. Taking this into account, this study aimed to determine the level of students' knowledge about the prevention of NSI and to examine the level of students' knowledge about post-exposure procedures among nursing students at the University of Applied Health Sciences in 2017.

\section{Methods}

\section{Participants}

The study was conducted in the second half of 2017. The respondents were full-time nursing students from all regions of Croatia, aged 18 to 28. All participants were fully informed about the aims of the study and provided written informed consent for participation in the study. The total number of respondents is 149. The questionnaire was designed specifically for this study and supplemented by a socio-demographic inquiry, and was personally delivered to all participants. Data collection was carried out at the University of Applied Health Sciences in Zagreb. Fifteen people who were offered participation chose not to participate. Data collection, preparation, implementation and presentation was in accordance with the legal requirements for the protection of the confidentiality of personal information, and approval for the study was obtained from the Ethics Committee of the University of Applied Health Studies (UR-2511-379-1-17-02).

\section{Instrument}

A specially designed questionnaire with 17 questions was used in the study. The respondents were offered multiple choices: 1) "yes", 2) "no" and 1) "yes", 2) "no" and 3) "not sure". One question had three subquestions and one had five subquestions regarding the knowledge of how to react if an NSI occurs. The participants also responded to a questionnaire on their socio-demographic data, including age, gender, year of study, type of secondary education, whether or not they have had an NSI and their vaccine status for hepatitis $\mathrm{B}$. The questions are divided in two groups. The first group is related to the perception of acquired knowledge and skills, and the second is about the specific issues of post-exposure procedures.

\section{Statistics}

Socio-demographic characteristics were analysed as categorical variables and are represented in numbers and relative frequency. Some dimensions contain more than one answer, while others include only one categorical answer. In case of lack of response to some questions, the average of the other answers was used, but only if at least half of the questions are answered (14-16). The statistical difference was determined using the Chi-Square Test. The values of $p<0.05$ are evaluated as statistically significant. Statistical analysis is performed by means of the electronic 24.0 SPSS Inc., Chicago, IL, SAD software.

\section{Results}

149 of the questionnaires were eligible for analysis. All of the respondents were full-time first-year nursing students, 69 of them (46\%), while 80 of them were third-year nursing students (54\%). Overall, the data included 134 (93\%) women and $15(7 \%)$ men. The largest number of the respondents was in the age range of 21 years. Most of the respondents have finished a "non-medical" secondary school, 95 of them (64\%), while 54 (36\%) of the respondents finished a "medical" secondary school. Furthermore, after the respondents filled in their sociodemographic data, they had to answer two questions. The first one was whether or not they have had an NSI and 
the second one was whether or not they have been vaccinated for hepatitis. 16 (11\%) students have had an NSI and one could not remember if they have had any. All students except one reported that they are vaccinated, but 50 (34\%) of the students were not sure about their vaccination status.

All of the respondents answered correctly to the question about whether it is necessary to wear protective gloves regardless of which secondary school they have finished.

\begin{tabular}{|c|c|c|c|}
\hline & $\begin{array}{l}\text { Secondary } \\
\text { "medical" } \\
\text { school }\end{array}$ & $\begin{array}{l}\text { Secondary } \\
\text { "non- } \\
\text { medical" } \\
\text { school }\end{array}$ & $\begin{array}{l}\text { Chi- } \\
\text { Square } \\
\text { Test }\end{array}$ \\
\hline Question & $\mathbf{N}$ & $\mathbf{N}$ & \\
\hline $\begin{array}{c}\text { After a needle } \\
\text { stick injury occurs, } \\
\text { it is necessary } \\
\text { to immediately } \\
\text { squeeze out blood } \\
\text { under water }\end{array}$ & 40 & 51 & 0.011 \\
\hline
\end{tabular}

Table 2. Number of respondents who answered correctly and the Chi-Square Test for obtained questions about acquired knowledge and skills

\begin{tabular}{|c|c|c|c|}
\hline $\begin{array}{l}\text { Answers to the } \\
\text { question: To } \\
\text { avoid needle } \\
\text { stick injury, it is } \\
\text { necessary to }\end{array}$ & $\begin{array}{l}\text { Secondary } \\
\text { "medical" } \\
\text { school }\end{array}$ & $\begin{array}{l}\text { Secondary } \\
\text { "non- } \\
\text { medical" } \\
\text { school }\end{array}$ & $\begin{array}{l}\text { Chi- } \\
\text { Square } \\
\text { Test }\end{array}$ \\
\hline $\begin{array}{l}\text { wear protective } \\
\text { gloves }\end{array}$ & 51 & 94 & 0.136 \\
\hline $\begin{array}{l}\text { put the cover back } \\
\text { on the needle }\end{array}$ & 37 & 41 & 0.002 \\
\hline $\begin{array}{c}\text { put the needle } \\
\text { into a special } \\
\text { container after } \\
\text { use }\end{array}$ & $54^{\star}$ & $95^{\star}$ & \\
\hline $\begin{array}{l}\text { The "safety- } \\
\text { system" reduces } \\
\text { the possibility of a } \\
\text { needle stick injury }\end{array}$ & $54^{\star}$ & $95^{\star}$ & - \\
\hline $\begin{array}{l}\text { It is necessary to } \\
\text { restrain a restless } \\
\text { patient or child }\end{array}$ & 52 & 92 & 0.598 \\
\hline *all students answered cor & & & \\
\hline
\end{tabular}

There is a statistically significant difference in the answers about interventions when an NSI occurs depending on which secondary school the participants finished. The respondents from medical schools answered correctly. There is also a statistically significant difference in answers to the question of whether to put the cover back on a needle, which is why we can conclude that the participants who finished a medical school have better knowledge.

\section{Table 3. Number of respondents who answered correctly and the Chi-Square Test for the question about post-exposure interventions

\begin{tabular}{cccc} 
& $\begin{array}{c}\text { Secondary } \\
\text { "medical" } \\
\text { school }\end{array}$ & $\begin{array}{c}\text { Secondary } \\
\text { "non- } \\
\text { medical" } \\
\text { school } \\
\text { N }\end{array}$ & $\begin{array}{c}\text { Chi- } \\
\text { Square } \\
\text { Test }\end{array}$ \\
$\begin{array}{c}\text { To whom would } \\
\text { you report a } \\
\text { needlestick injury? }\end{array}$ & 53 & 92 & 0.370 \\
\hline
\end{tabular}

\begin{tabular}{|c|c|c|c|}
\hline \multicolumn{4}{|c|}{$\begin{array}{l}\text { Table 4. Number of respondents who } \\
\text { answered correctly and the Chi-Square Test } \\
\text { for obtained questions about post-exposure } \\
\text { interventions }\end{array}$} \\
\hline $\begin{array}{l}\text { Which } \\
\text { interventions } \\
\text { need to be } \\
\text { implemented } \\
\text { after a needle } \\
\text { stick injury: }\end{array}$ & $\begin{array}{l}\text { Number of } \\
\text { students } \\
\text { who } \\
\text { finished a } \\
\text { "medical" } \\
\text { secondary } \\
\text { school and } \\
\text { answered } \\
\text { correctly }\end{array}$ & $\begin{array}{l}\text { Secondary } \\
\text { "non- } \\
\text { medical" } \\
\text { school }\end{array}$ & $\begin{array}{l}\text { Chi- } \\
\text { Square } \\
\text { Test }\end{array}$ \\
\hline $\begin{array}{l}\text { Blood testing- } \\
\text { victim }\end{array}$ & 53 & 94 & 0.595 \\
\hline $\begin{array}{l}\text { Blood testing- } \\
\text { patient }\end{array}$ & 43 & 86 & 0.054 \\
\hline $\begin{array}{l}\text { Post-exposure } \\
\text { monitoring }\end{array}$ & 54 & 93 & 0.635 \\
\hline $\begin{array}{l}\text { Post-exposure } \\
\text { education }\end{array}$ & 46 & 90 & 0.048 \\
\hline
\end{tabular}

There is no statistical difference in the answers about who they would report the needlestick injury to. Furthermore, there is no statistical difference in the answers about whether it is necessary to take blood for serological testing for patients and injured persons, or in the answers regarding the necessity of monitoring over three months. 
There is a statistically significant difference in the answers about conducting education on post-exposure interventions. The respondents from a nonmedical secondary school had higher scores, i.e. most of them answered correctly.

When all 5 questions about post-exposure interventions were obtained and combined into one variable, a total level of knowledge in this aspect was obtained and each subject could accumulate a score between 0 to 4 . Table 3 gives the average score in that variable with regard to which secondary school the respondents finished, and it can be seen that, on average, more points are obtained by respondents from non-medical schools. Table 4 shows that this difference is statistically significant $(t=-2.43$, significance 0.016 , ie $p<0.05$ ).

\section{Discussion}

This is the first such study conducted at the University of Applied Health Sciences to examine the knowledge of nursing students of NSI. The healthcare profession has been characterized as a profession that is at high risk of NSI and therefore the transmission of infection. Lack of experience or training, overload and fatigue are the most common causes of NSI (1719). In a study conducted by Askarian et al., most of the interviewed nurses, $52.5 \%$ of them, reported an NSI more than once a year (20). Shiao et al. examined the incidence of NSI in students in Taiwan and reported that $61.9 \%$ of them experienced an NSI, mostly in hospital rooms (70.1\%) (8) during venepuncture or administration of IV therapy (21). Furthermore, an often unreported NSI indicates a lack of knowledge of the reporting system or lack of knowledge of the reporting process and the importance of recording NSI (21). This is different from our results, which show that students, especially those who have finished a medical school, correctly answered the questions about post-exposure procedure. All of the respond-

\section{Table 5. Group statistics for obtained questions about post-exposure interventions}

$\begin{array}{cccccc} & \begin{array}{c}\text { Secondary } \\ \text { school }\end{array} & \text { N } & \text { Mean } & \text { Std. Deviation } & \text { Std. Error Mean } \\ \text { post-exposure interventions } & 1 & 54 & 3.6296 & 0.55952 & 0.07614 \\ \text { *Medical school (1); Non-medical school (2) } & 2 & 94 & 3.8298 & 0.43101 & 0.04446\end{array}$

\section{Table 6. Independent samples test for obtained questions about post-exposure interventions}

Levene's Test

for Equality

of Variances

$\mathbf{F}$
Sig.
$\mathbf{t}$
Df
Sig. (2-tailed)
Mean Difference
Std. Error Difference

Equal

Post-

variances
assumed
Equal
variances

$\begin{array}{lll}16.284 & 0.000 & -2.434\end{array}$

146

0.016

$-0.20016$

exposure

\footnotetext{
not assumed
}

$-2.270$

89.37

0.026

$-0.20016$

0.08224

95\% Confidence

Interval of the

Difference

Lower Upper

interventions

0.08817

$-0.37534$

$-0.02498$ 
ents are aware that an NSI can transmit infectious diseases, while students who have finished a medical school achieved, on average, higher results regarding the procedure during and after NSI. There is a statistically significant difference in the answers to the question of whether to replace the needle cap depending on the type of school, with significantly more correct answers given by the respondents from medical schools, which is contrary to the research of Suliman et al., who claimed that half of the nurses did not know that it was not a standard procedure to replace the protective cap after using a needle (9). In the same study, even fewer respondents (34.8\%) knew which procedures needed to be performed after exposure to an NSI, which is also different from our results where students showed a high level of knowledge regarding post-exposure interventions (9). High results related to wearing gloves is correlated with the results of our study, where most students report wearing gloves when handling sharp objects (21), while Vandijki statistically showed that $88.7 \%$ of students provided the correct answer to the question of when to use gloves, and $60.2 \%$ recognized the importance of wearing protective clothing (21-22). Students are aware of the importance of vaccination, prophylaxis and reprophylaxis, and all report being vaccinated, which is similar to other studies where as many as $96 \%$ of the students reported being vaccinated against the hepatitis $B$ virus (23). The percentage of needle stick injuries among the respondents is not significantly high, but a higher number of respondents could change the results of the study. Studies conducted on a large number of students indicate a relatively high incidence of NSI during exercise classes (23), with Liu et al. reporting an incidence of $60.8 \%$ among students. They proved that the incidence of NSI was significantly higher in the early stage of internships, and higher in the daytime shift than the night shift. Furthermore, the incidence of needle stick injuries was higher during the removal of a needle for the administration of therapy or infusion, accounting for $24.3 \%$ of the total incidence (24). The high incidence of NSI (39.76\%), mostly during the first year of study, was also recorded in a study by Prasuna et al. conducted among nursing students, which showed that respondents were unaware of the measures to be taken after exposure (2). Masaaro included 223 students in the final year of study, and the incidence of NSI was $18 \%$ (25), which is similar to the results of Stefanati et al., whose study showed that the incidence was $18.82 \%$
(26). In order to develop further prevention measures and strategies and minimize adverse events, it is important to provide ongoing training in the prevention of NSI, post-exposure procedures, and simulation exercises prior to clinical practice for students.

The students' knowledge of NSI is satisfactory. They were educated about the possibility of risk, post-exposure procedures and prevention. However, it is obvious that the students who have finished a medical high school had a higher level of knowledge in these areas. Due to different groups of students, education about NSI should begin from the first year of study.

One suggestion for future research is to conduct a study on a larger sample of participants and on parttime nursing students.

\section{Conclusion}

NSI represents an occupational hazard for health care workers. Nursing students are at a high risk of NSI due to a lack of knowledge and clinical experience. In order to ensure their safety and improve their knowledge, it is important to identify strategies for the prevention of NSI. Nursing students in Croatia have moderate knowledge about the prevention of NSI and post-exposure procedures. The results of this study show that students who have finished a medical secondary school showed better results when answering questions about interventions for the prevention of needle stick injuries, while students who have finished a non-medical school show better results when answering questions about postexposure interventions.

Finally, the results of this study can be used to establish appropriate education strategies, increase the awareness of needle stick injuries and minimize the occurrence of these injuries among nursing students in Croatia. 


\section{References}

1. Norsayani MY, Noor Hassim I. Study on incidence of needle stick injury and factors associated with this problem among medical students. J Occup Health. 2003;45(3):172-8.

2. Prasuna J, Sharma R, Bhatt A, Arazoo, Painuly D, Butola $\mathrm{H}$, et al. Occurrence and knowledge about needle stick injury in nursing students. J Ayub Med Coll Abbottabad. 2015;27(2):430-3.

3. Benner P, Sutphen M, Leonard V, Day L. Educating Nurses: A Call for Radical Transformation. 1st ed. San Francisco: Jossey-Bass; 2010.

4. Cheung K, Ho SC, Ching SS, Chang KK. Analysis of needlestick injuries among nursing students in Hong Kong. Accid Anal Prev. 2010;42(6):1744-50.

5. Smith DR, Leggat PA. Needlestick and sharps injuries among nursing students. J Adv Nurs. 2005;51(5):44955.

6. Talas MS. Occupational exposure to blood and body fluids among Turkish nursing students during clinical practice training: frequency of needlestick/sharp injuries and hepatitis B immunisation. J Clin Nurs. 2009;18(10):1394-403.

7. Yao WX, Yang B, Yao C, Bai PS, Qian YR, Huang CH, et al. Needlestick injuries among nursing students in China. Nurse Educ Today. 2010;30(5):435-7.

8. Shiao JS, Mclaws ML, Huang KY, Guo YL. Student nurses in Taiwan at high risk for needlestick injuries. Ann Epidemiol. 2002;12(3):197-201.

9. Suliman M, Al Qadire M, Alazzam M, Aloush S, Alsaraireh $A$, Alsaraireh FA. Students nurses' knowledge and prevalence of Needle Stick Injury in Jordan. Nurse Educ Today. 2018;60:23-7.

10. Hambridge K. Needlestick and sharps injuries in the nursing student population. Nurs Stand. 2011;25(27):38-45.

11. Handiyani H, Meily Kurniawidjaja L, Irawaty D, Damayanti $R$. The effective needle stick injury prevention strategies for nursing students in the clinical settings: a literature review. Enferm Clin. 2018;28 Suppl 1:167-71.

12. El Beltagy K, El-Saed A, Sallah M, Balkhy HH. Impact of infection control educational activities on rates and frequencies of percutaneous injuries (PIs) at a tertiary care hospital in Saudi Arabia. J Infect Public Health. 2012;5(4):297-303.

13. Yao WX, Wu YL, Yang B, Zhang $L Y$, Yao $C$, Huang $C H$, et al. Occupational safety training and education for needlestick injuries among nursing students in China: intervention study. Nurse Educ Today. 2013;33(8):834-7.

14. Tkalac Verčić A, Sinčić Ćorić D, Pološki Vokić N. Priručnik za metodologiju istraživačkog rada - Kako osmisliti, provesti i opisati znanstveno i stručno istraživanje. Zagreb: M.E.P; 2010. Croatian.

15. Petz B, Kolesarić V, Ivanec D. Petzova statistika. Osnovne statističke metode za nematematičare. Jastrebarsko: Naklada Slap; 2012. Croatian.

16. Šošić I. Primijenjena statistika. Zagreb: Školska knjiga; 2006. Croatian.

17. Phipps W, Honghong W, Min Y, Burgess J, Pellico L, Watkins $C$, et al. Risk of medical sharps injuries among Chinese nurses. Am J Infect Control. 2002;30(5):277-82.

18. Rogers B, Goodno L. Evaluation of interventions to prevent needlestick injuries in health care occupations. Am J Prev Med. 2000;18(4 Suppl):90-8.

19. Rubbi I, Cremonini V, Butuc A, Cortini C, Artioli G, Bonacaro $A$, et al. Incidence and type of health care associated injuries among nursing students: an experience in northern Italy. Acta Bio Med. 2018;89(7-5):41-9.

20. Ayranci U, Kosgeroglu N. Needlestick and sharps injuries among nurses in the healthcare sector in a city of western Turkey. J Hosp Infect. 2004;58(3):216-23.

21. Askarian M, Malekmakan L, Memish ZA, Assadian 0. Prevalence of needle stick injuries among dental, nursing and midwifery students in Shiraz, Iran. GMS Krankenhhyg Interdiszip. 2012;7(1):Doc05.

22. Vandijck DM, Labeau SO, De Somere J, Claes B, Blot Sl; Executive Board of the Flemish Society of Critical Care Nurses. Undergraduate nursing students' knowledge and perception of infection prevention and control. J Hosp Infect. 2008;68(1):92-4.

23. Yang $Y$, Wu M, Ho C, Chuang $H$, Chen L, Yang C, et.al. Needlestick/sharps injuries among vocational school nursing students in southern Taiwan. Am J Infect Control. 2004;32(8):431-5.

24. Liu C, Liu X, Zhu Y, Liu Y. [Influencing factors for needlestick injuries in student nurses]. Zhonghua Lao Dong Wei Sheng Zhi Ye Bing Za Zhi. Chinese Journal of industrial hygiene and occupational disease. 2015;33(7):528-31. Chinese.

25. Massaro T, Cavone D, Orlando G, Rubino M, Ciciriello M, Musti EM. Infortuni da dispositivi taglienti tra gli studenti di infermieristica: un rischio lavorativo emergente [Needlestick and sharps injuries among nursing students: an emerging occupational risk]. G Ital Med Lav Ergon. 2007;29(3 Suppl):631-2. Italian.

26. Stefanati A, Boschetto P, Previato S, Kuhdari P, De Paris $P$, Nardini $M$, et al. Indagine sugli infortune tra il personale infermieristico e gli studenti del corso di laurea in infermieristica: analisi epidemiologica descrittiva nel period 2002-2012 in un'Azienda OspedalieroUniversitaria [A survey on injuries among nurses and nursing students: a descriptive epidemiologic analysis between 2002 and 2012 at a University Hospital]. Med Lav. 2015;106(3):216-29. Italian. 


\section{ZNANJE STUDENATA STUDIJA SESTRINSTVA O PREVENCIJI I POIMANJU UBODNOG INCIDENTA}

\section{Sažetak}

Uvod. Ubodni incident predstavlja problem povezan s profesionalnim zdravljem i sigurnošću. Studenti sestrinstva skloni su nastanku ubodnog incidenta zbog nedostatka iskustva pri rukovanju iglama i oštrim predmetima.

Cilj. Odrediti razinu znanja o prevenciji i postekspozicijskoj proceduri te poimanju ubodnog incidenta.

Metode. Istraživanje je provedeno tijekom 2017. godine na Zdravstvenom veleučilištu u Zagrebu. Sudionici su bili studenti studija sestrinstva u dobi od 18 godina i više. Podaci su prikupljeni s pomoću upitnika koji sadrži 17 pitanja, posebno dizajniranog za ovo istraživanje. Prvo pitanje imalo je imalo tri potpitanja, drugo pet potpitanja povezanih sa znanjem kako reagirati ako se dogodi ubodni incident, a treće trinaest potpitanja povezanih s percepcijom opasnosti ubodnog incidenta s obzirom na karakteristike pacijenata. Sudionici su također odgovorili na pitanja o sociodemografskim podacima.

Rezultati. U istraživanju je sudjelovalo 149 studenata. Rezultati istraživanja utvrdili su kako je 16 studenata doživjelo ubodni incident. Utvrđena je statistički značajna razlika kod studenata koji su završili srednju medicinsku školu u odgovorima povezanima s intervencijama u slučaju ubodnog incidenta i u odgovorima na pitanje o tome treba li vratiti poklopac na iglu nakon upotrebe. Studenti koji su završili srednju medicinsku školu odgovorili su točno. Statistički značajna razlika utvrđena je kod studenata koji nisu završili srednju medicinsku školu u odgovorima povezanima s postekspozicijskim mjerama i intervencijama nakon pojave ubodnog incidenta. Studenti koji nisu završili srednju medicinsku školu imali su bolji rezultat.

Zaključak. Rezultati ovog istraživanja mogu se upotrijebiti za izradu odgovarajućih obrazovnih strategija za povećanje svijesti o ubodnom incidentu te prevenciju njegove pojave među studentima sestrinstva u Hrvatskoj.

Ključne riječi: ubodni incident, studenti sestrinstva, preventivni programi 